\title{
Protecting biodiversity in British Columbia: Recommendations for developing species at risk legislation
}

\begin{abstract}
Alana R. Westwood ${ }^{a \dagger}$, Sarah P. Otto ${ }^{b \ddagger \star}$, Arne Mooers ${ }^{c \ddagger}$, Chris Darimont ${ }^{\mathrm{d} *}$, Karen E. Hodges ${ }^{\mathrm{e} \ddagger}$, Chris Johnson $^{\mathrm{f} *}$, Brian M. Starzomski ${ }^{\mathrm{g} \ddagger}$, Cole Burton ${ }^{\mathrm{h}}$, Kai M.A. Chan ${ }^{\mathrm{i}}$, Marco Festa-Bianchet ${ }^{j}$, Shaun Fluker ${ }^{k}$, Sumeet Gulati ${ }^{1}$, Aerin L. Jacob ${ }^{a}$, Dan Kraus ${ }^{\mathrm{m}}$, Tara G. Martin ${ }^{\mathrm{n}}$, Wendy J. Palen ${ }^{\circ}$, John D. Reynolds ${ }^{o}$, and Jeannette Whitton ${ }^{p}$

${ }^{a}$ Yellowstone to Yukon Conservation Initiative, 200-1350 Railway Avenue, Canmore, AB T1W 1P6, Canada; ${ }^{b}$ Biodiversity Research Centre \& Department of Zoology, The University of British Columbia, 6270 University Boulevard, Vancouver, BC V6T 1Z4, Canada; ${ }^{\circ}$ Department of Biological Sciences, Simon Fraser University, Burnaby, BC V5A 1S6, Canada; ${ }^{\mathrm{d} D e p a r t m e n t ~ o f ~ G e o g r a p h y, ~ U n i v e r s i t y ~ o f ~ V i c t o r i a, ~}$ P.O. Box 1700 STN CSC, Victoria, BC V8W 2Y2, Canada; ${ }^{e}$ Department of Biology, The University of British Columbia-Okanagan Campus, 1177 Research Road, Kelowna, BC V1V 1V7, Canada; ${ }^{\mathrm{f}}$ Ecosystem Science \& Management Program, University of Northern British Columbia, 3333 University Way, Prince George, BC V2N 4Z9, Canada; ${ }^{\text {gS }}$ chool of Environmental Studies, University of Victoria, P.O. Box 3060 STN CSC, Victoria, BC V8W 3R4, Canada; ${ }^{\mathrm{h}}$ Department of Forest Resources Management, The University of British Columbia, 2424 Main Mall, Vancouver, BC V6T 1Z4, Canada; ${ }^{\mathrm{i}}$ Institute for Resources, Environment and Sustainability, The University of British Columbia, 2202 Main Mall, Vancouver, BC V6T 1Z4, Canada; 'Département de biologie, Université de Sherbrooke, Sherbrooke, QC J1K 2R1, Canada; ${ }^{k}$ Faculty of Law, University of Calgary, 2500 University Drive NW, Calgary, AB T2N 1N4, Canada; 'Faculty of Land and Food Systems, The University of British Columbia, 2357 Main Mall, Vancouver, BC V6T 1Z4, Canada; ${ }^{\mathrm{m}}$ School of Environment, Resources and Sustainability, University of Waterloo, Waterloo, ON N2L 3G1, Canada; ${ }^{\mathrm{n}}$ Department of Forest and Conservation Sciences, The University of British Columbia, 2424 Main Mall, Vancouver, BC V6T 1Z4, Canada; ${ }^{\circ}$ Earth to Ocean Research Group, Simon Fraser University, 8888 University Drive, Burnaby, BC V5A 1S6, Canada; ${ }^{\mathrm{p}}$ Biodiversity Research Centre \& Department of Botany, The University of British Columbia, 6270 University Boulevard, Vancouver, BC V6T 1Z4, Canada

*otto@zoology.ubc.ca

${ }^{\dagger}$ Facilitator, lead author based on the recommendations of the expert team

${ }^{\ddagger}$ Expert team leads
\end{abstract}

\begin{abstract}
British Columbia has the greatest biological diversity of any province or territory in Canada. Yet increasing numbers of species in British Columbia are threatened with extinction. The current patchwork of provincial laws and regulations has not effectively prevented species declines. Recently, the Provincial Government has committed to enacting an endangered species law. Drawing upon our scientific and legal expertise, we offer recommendations for key features of endangered species legislation that build upon strengths and avoid weaknesses observed elsewhere. We recommend striking an independent Oversight Committee to provide recommendations about listing species, organize Recovery Teams, and monitor the efficacy of actions taken. Recovery Teams would evaluate and prioritize potential actions for individual species or groups of species that face common threats or live in a common area, based on best available evidence (including natural and social science and Indigenous Knowledge). Our recommendations focus on implementing an adaptive approach, with ongoing and transparent monitoring and reporting, to reduce delays between determining when a species is at risk and taking effective actions to save it. We urge
\end{abstract}


lawmakers to include this strong evidentiary basis for species recovery as they tackle the scientific and socioeconomic challenges of building an effective species at risk Act.

\section{Résumé}

Au Canada, c'est en Colombie-Britannique que la biodiversité est la plus élevée. Pourtant, un nombre croissant de ces espèces sont menacées. L'actuel enchevêtrement de lois et de règlements provinciaux ne parvient pas à en prévenir le déclin. Récemment, le gouvernement provincial s'est engagé à adopter une loi sur les espèces en péril. En nous appuyant sur notre expertise légale et scientifique et sur les succès et échecs connus ailleurs, nous proposons les éléments clés que devrait présenter cette loi. Nous recommandons la formation d'un Comité indépendant de surveillance qui évaluera le statut des espèces, organisera les Équipes de rétablissement et estimera l'efficacité des mesures de protection adoptées. Les Équipes de rétablissement prioriseront les actions possibles pour chaque espèce ou groupe d'espèces subissant les mêmes menaces ou habitant la même région en s'appuyant sur les meilleures informations disponibles (sciences naturelles et sociales et savoirs autochtones). Nos recommandations visent à établir une approche adaptative, incluant un suivi régulier et transparent, afin de réduire les délais entre l'établissement du statut et la mise en œuvre d'actions de rétablissement. Nous exhortons les législateurs et législatrices à tenir compte de cette approche basée sur les éléments probants relatifs au rétablissement des espèces.

\section{BC NEEDS TO GET ITS ENDANGERED SPECIES ACT TOGETHER}
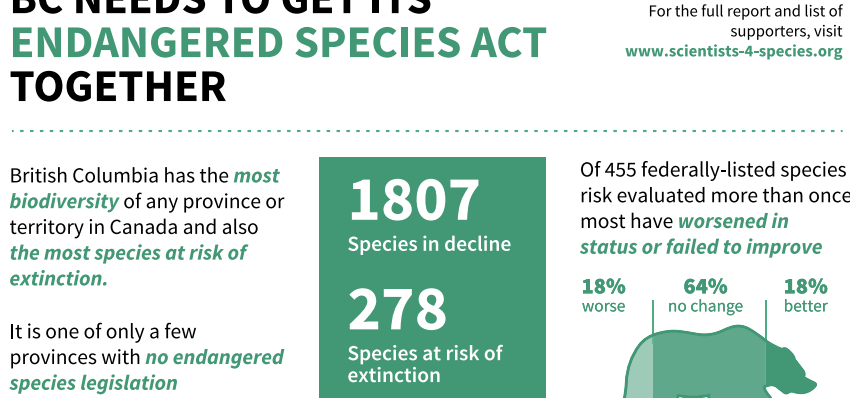

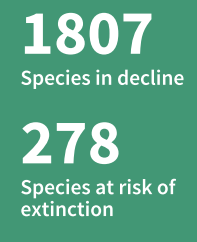

Of 455 federally-listed species at risk evaluated more than once, most have worsened in status or failed to improve \begin{tabular}{l|l|l}
\begin{tabular}{l|l}
$18 \%$ \\
worse
\end{tabular} & $64 \%$ & $18 \%$ \\
& no change & bette
\end{tabular}

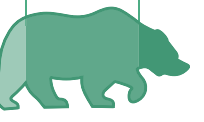

\section{WHAT SCIENTISTS PROPOSE}

Our species at risk expert panel recommends an endangered species law that promotes the recovery of species at risk and simultaneously safeguards BC's biodiversity. This law should:

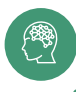

Commit to species recovery within a broad and integrated framework

- Integrate with the provincial land-use planning framework

- Ensure sustained funding

- Commit to scientific integrity: rigour transparency, independence, and open data

Implement effective protection and stewardship

- Implement automatic protections on Crown land and work with landholders to apply additional protections

- Use permits and exemptions sparingly and with justification

- Support evidence-based stewardship

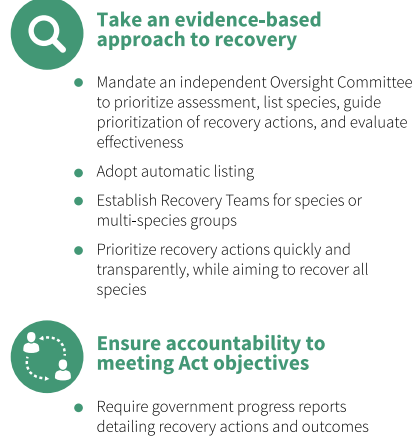

Key words: species at risk, legislation, conservation, endangered, recovery, prioritization 


\section{Introduction}

British Columbia (B.C.) has the most biodiversity of any Canadian province (Cannings et al. 2005; Austin et al. 2008) and also the most species assessed to be at risk. The B.C. Conservation Data Centre (BCCDC) has identified 1807 wildlife species (henceforth "species") at risk, including those with declining populations, small populations, and restricted ranges (B.C. Conservation Data Centre 2018). As part of national evaluations, the Committee on the Status of Endangered Wildlife in Canada (COSEWIC) has assessed 278 species at risk of extinction within B.C. (extirpated, endangered, threatened, or special concern); 214 of these are legally listed under the federal Species At Risk Act (SARA, 2002; Government of Canada 2018a).

In 1996, B.C. signed on to the national Accord for the Protection of Species at Risk (Government of Canada 2018a), supporting the position that Canada's biodiversity offers benefits to people and should be protected. Although prevention is widely recognized as the best approach for conserving biodiversity (BCMECCS 2018), additional measures are needed to recover species at risk of extirpation or extinction. Like several other Canadian provinces and territories (Alberta, Saskatchewan, Prince Edward Island, Yukon, and Nunavut), B.C. has never had dedicated species at risk legislation and instead has been relying on an inadequate patchwork of legislation and resulting policy decisions to manage species at risk (e.g., the Wildlife Act (1996), the Forest \& Range Practices Act (2002), and the Oil and Gas Activities Act (2008)). These legislative and policy frameworks were not intended to protect species at risk; the province has repeatedly been criticized for prioritizing resource development over the needs of species (Sierra Legal and Environmental Law Centre 2007; British Columbia Task Force on Species At Risk 2011; BCMECCS 2018).

In 2013, B.C.'s Auditor General found that the government was not doing enough to address biodiversity declines, particularly by not fully implementing or monitoring its own habitat-protection tools (Office of the Auditor General of British Columbia 2013). Several bills have been tabled in B.C.'s legislature to protect the province's species at risk, ${ }^{1}$ but none of these opposition-led bills passed first reading.

B.C. is seeking to implement strong and effective species at risk legislation (BCMECCS 2018). The national benchmark legislation, $S A R A$, has been plagued with issues related to timeliness and effectiveness. For most listed species, the federal government has failed to meet legal timelines (Bird and Hodges 2017) and has made little progress towards recovery goals (a pattern that holds broadly across monitored vertebrate taxa; WWF-Canada 2017; Environment and Climate Change Canada 2018a) Furthermore, there are taxonomic biases, with mosses and lichens more likely to have designated critical habitats than vertebrates (Bird and Hodges 2017). Similar problems in implementing species at risk legislation exist elsewhere: under Australia's Environmental Protection and Biodiversity Conservation Act (1999), where key tools such as protecting critical habitat are discretionary, $<1 \%$ of listed species had critical habitat designated and protected as of 2017 (Martin et al. 2017). In the United States, identifying and protecting critical habitat under the Endangered Species Act has lagged as agencies make ample use of legislative exemptions (Hagen and Hodges 2006).

In 2017, B.C.'s newly elected government assigned the Minister of Environment and Climate Change Strategy the mandate to enact endangered species law. In 2018, the government of B.C. began to consult the public in advance of drafting legislation. The province stated a goal of "[managing] humanrelated activities so that: species are recovered and are no longer considered at risk; species at risk are safeguarded from further threats; and native species are not lost from B.C. (BCMECCS 2018, p. 10),"

${ }^{1}$ Including the Wildlife Protection Act, 2008 by Shane Simpson (New Democratic Party; NDP); the Species at Risk Protection Act, 2010 and 2011 by Rob Fleming (NDP); the Endangered Species Act, 2017 by Andrew Weaver (Green Party), and the Species at Risk Protection Act, 2017 by George Heyman (NDP). 
goals akin to the framing statements of species-at-risk legislation in other jurisdictions. We refer to this as-yet undrafted legislation as the British Columbia Species At Risk Protection and Recovery Act (hereafter BCSARPRA or "the Act").

Overall, we recommend that the legislation be written as a platform for a systematic, planned, and evidence-informed approach that protects and recovers species at risk across the entire province and that includes Indigenous peoples and other parties as partners in conservation. Our recommendations are grounded in our scientific training and expertise in species at risk policy and recovery. Collectively, we have served on COSEWIC, the Species at Risk Advisory Committee of Canada, and the Species Survival Commission and specialist committees for the International Union for Conservation of Nature (IUCN), have published dozens of papers and reports on science policy issues, and have provided expert advice to governments (Indigenous and municipal governments, provincial and national governments, and international intergovernmental organizations) on biodiversity issues. Our recommendations here are focused on lands and waters under jurisdiction claimed by British Columbia. We recognize section 35 rights of Indigenous peoples under Canada's Constitution, the commitments of the provincial and federal governments to the U.N. Declaration on the Rights of Indigenous Peoples (UNDRIP), and that Indigenous peoples have unique rights and interests in the use, management, and conservation of biodiversity. We recognize the possibility that endangered species legislation may conflict with the sovereign interests of Indigenous peoples, including their interests in harvesting and recovering species at risk. We support the objective of reconciliation, and we urge the B.C. government to engage on a nation-to-nation basis when developing the BCSARPRA and its associated policies. ${ }^{2}$

\section{Recommendations}

Our recommendations for BCSARPRA focus on committing to strong principles of precaution and scientific integrity, as well as enshrining a process focused on implementing recovery action with independent oversight. We propose specific tools and approaches to avoid the delays in listing species, designating critical habitat, and implementing recovery actions that have plagued species at risk laws in other jurisdictions. We make recommendations for legislation that emphasize immediate and efficient recovery action within an evidence-based, transparent, inclusive, and adaptive management framework (Box 1). Our recommendations are:

\section{Commit to species recovery within a broad and integrated framework}

The purpose of the Act should be to prevent wildlife species from becoming extirpated or extinct in British Columbia, to provide for the recovery of wildlife species that are endangered or threatened, and to prevent healthy populations from becoming imperiled. The Act should acknowledge that the Crown owns and holds wildlife species in trust for the present and future generations of British Columbians and that the Crown recognizes the many values of wildlife species (including nonmonetary and non-use values) and commits to protect them.

The government's 2018 primer to support discussion on new species at risk legislation states the need for a law that "does not use a lack of scientific information as a reason to postpone protecting a species

\footnotetext{
${ }^{2}$ See, for example, guidelines on appropriate process and protocols for use of Traditional Knowledge developed by COSEWIC: canada.ca/en/environment-climate-change/services/committee-status-endangered-wildlife/ aboriginal-traditional-knowledge.html.

${ }^{3}$ Since being articulated in the World Charter for Nature, World Conservation Strategy, Earth Charter, and the Convention on Biodiversity, a growing number of laws around the world acknowledge the intrinsic value of other species. These include laws in Costa Rica, Canada, Bangladesh, Israel, Japan, Tanzania, New Zealand, and the European Union. The Northwest Territories' Wildlife Act 2013, a law heavily influenced by Indigenous peoples, states (pp. 20-21) "Wildlife is to be conserved for its intrinsic value and for the benefit of present and future generations."
} 
Box 1. Specific recommendations.

1. Commit to principles of recovery, precaution, and feasibility

1.1 Integrate with provincial land-use planning framework

1.2 Ensure sustained funding

1.3 Commit to scientific integrity: rigour, transparency, independence, and open data

2. Take an evidence-based approach to recovery

2.1 Mandate an independent Oversight Committee to prioritize assessment, list species, guide prioritization of recovery actions, and evaluate effectiveness

2.2 Adopt automatic listing

2.3 Establish Recovery Teams for species or multi-species groups

2.4 Prioritize recovery actions quickly and transparently, while aiming to recover all species, in the form of a living document that allows for adaptive management

3. Implement effective protections and stewardship, including:

3.1 Implement automatic protections on Crown land and work with landholders to obtain additional protections

3.2 Use permits and exemptions sparingly and with justification

3.3 Support evidence-based stewardship

4. Ensure accountability to meet Act objectives

4.1 Require government progress reports detailing the implementation of recovery actions

4.2 Mandate arms-length reviews of the effectiveness of the Act

at risk if there are significant threats to that species" (BCMECCS 2018, p. 10). We wholeheartedly support this approach, which aligns with decades of scientific literature (Kriebel et al. 2001; Gregory and Long 2009), reflects best practice in the field of environmental management (Lauck et al. 1998), is a core policy principle of SARA (Government of Canada 2016a), and is consistent with international guidelines on species assessments (e.g., IUCN Red List). Furthermore, socioeconomic considerations should not trump ecological ones in cases of imminent imperilment, a principle supported by recent Canadian case law (Groupe Maison Candiac Inc. v. Canada (Attorney General), 2018 FC 643).

Definitions of technical terms describing a species, ${ }^{4}$ survival, recovery, critical habitat, ${ }^{5}$ and others should be consistent with definitions used at the federal level to minimize conflicts in objectives and assessment. In particular, the current proposed SARA policy suite defines species "survival" as applying when a species surpasses a threshold for persistence, and species "recovery" as a higher threshold

${ }^{4}$ SARA 2002 subsection 2(1): "a species, subspecies, variety, or geographically or genetically distinct population of animal, plant or other organism, other than a bacterium or virus, that is wild by nature and is either native to Canada or has extended its range into Canada without human intervention and has been present in Canada for at least 50 years."

${ }^{5}$ SARA, 2002 subsection 2(1): "the habitat that is necessary for the survival or recovery of a listed wildlife species and that is identified as the species' critical habitat in the recovery strategy or in an action plan for the species." 
that also ensures that the range and genetic diversity of the species are represented (Government of Canada 2016b). Specifying objective and practical targets for recovery can incentivize conservation actions to move species onto a "green list" of success (Akçakaya et al. 2018).

\section{I.I Integrate with provincial land-use planning framework}

Biodiversity management requires both "coarse-filter" (e.g., representative parks and protected areas, coordinated development at the landscape level) and "fine-filter" (e.g., species-specific) approaches. In this paper, we focus our comments on the fine-filter species-based legislation currently being considered by the B.C. government. Anthropogenic effects are taking a toll on wildlife (Shackelford et al. 2018), with many species potentially subject to thresholds beyond which they cannot recover (McLellan et al. 2010). For most species, these critical thresholds are not yet known (Hunter et al. 2009). For well-studied species where habitat disturbance thresholds have been identified (e.g., grizzly bears (Ursus arctos ssp.) and boreal caribou (Rangifer tarandus caribou)), these limits are often exceeded (Environment and Climate Change Canada 2018b; Proctor et al. 2018). Cumulative effects (e.g., the effects of multiple interacting stressors, such as climate change, habitat loss, and pollution) threaten biodiversity across large parts of B.C., particularly mammals with large distributions and ecosystems with high levels of conversion (Shackelford et al. 2018).

We recognize that laws managing the protection and recovery of endangered species must link to other development and economic actions, both private and public. To halt ongoing declines and accomplish the goals of recovery, many species will require actions taken on a large spatial scale that involve many parties. For this reason, every environmental impact assessment or cumulative effects assessment should consider effects on endangered species, taking a precautionary approach in the case of data deficiencies. Other provincial legislation (e.g., Forest \& Range Practices Act, 2002 and Environmental Assessment Act, 2002) would need to be amended to allow for the implementation of required recovery actions as prescribed under the BCSARPRA.

\section{I.2 Ensure sustained funding}

No matter how well-crafted the text of a BCSARPRA, the Act cannot accomplish its objectives unless it is sufficiently financed for people to carry out the programs and activities it prescribes (British Columbia Task Force on Species At Risk 2011). Such activities include the infrastructure to support species listing and Recovery Teams, private land stewardship initiatives, habitat restoration, removal of invasive species, species monitoring, and, where necessary, research for filling critical knowledge gaps. Government capacity will be needed to manage these processes and ensure they are achieved within mandated timelines. The government should ensure sufficient and stable funding to administer the Act, including reporting and supporting prioritized actions. We recognize that the budgetary process is the responsibility of government and that budgets will vary according to economic circumstances and provincial priorities. However, recovery is a multi-year process and success is dependent on reliable funding. We strongly caution against relying on funding from external bodies (e.g., B.C. Parks Foundation or Habitat Conservation Trust Foundation) in lieu of consistent provincial financial support.

\section{I.3 Commit to scientific integrity}

As governments and society both recognize the importance for science to be conducted and communicated transparently, commitments to scientific integrity are increasingly common in legislation and policy. For instance, a provision for government scientific integrity, honesty, objectivity, thoroughness, and accuracy has been proposed for Canada's next federal impact assessment law (House of Commons of Canada 2018). All of Canada's federal scientific departments were mandated to implement scientific integrity policies by the end of 2018 (Innovation Science and Economic Development Canada 2018). These policies are meant to allow federal scientists to conduct their work 
without political interference, communicate freely, and ensure that their scientific findings are available to the public. The Government of B.C. has also recognized the importance of professional independence and integrity to enhance public confidence in natural resource decision-making (Haddock 2018).

The BCSARPRA should explicitly support the following components of scientific integrity (adapted from Jacob et al. 2018; Westwood et al. 2019): scientific rigour, transparent decision-making, independent advisors, and open information (Box 2).

Box 2. Components of scientific integrity.

\section{Scientific rigour}

Although scientific evidence is commonly used in public policy, it is not always used effectively (Gosselin et al. 2010). The best available methods should be used to collect and analyze data related to the Act. Data, metadata, associated results, and their interpretation, as well as their application in evidence-based decision-making, should adhere to evolving best scientific practices, including being subject to standards of peer review where applicable (SAGE 1999; Ryder et al. 2010; Science Integrity Project 2015). Cumulative effects should be rigorously considered in species at risk assessment and recovery planning. Lacking full knowledge of threats or their interactions should not be used as a reason to delay recovery actions.

Transparent decision-making

Although species assessment should be informed by evidence, including Indigenous and local knowledge, socioeconomic considerations will come into play when applying protections, assessing threats, and prioritizing, planning, and implementing recovery actions. It is essential for the public to be informed about how and where different forms of evidence were considered and on what basis decisions were made. In the past, decisions regarding wildlife management in B.C. (British Columbia Task Force on Species At Risk 2011) and across Canada and the United States (Artelle et al. 2018; Nichols et al. 2018) have been criticized for lacking transparency. Transparent decision-making for a proposed Act is supported by the government (BCMECCS 2018), and we encourage an explicit statement in BCSARPRA committing to this principle.

\section{Independent advisors}

Duties related to species at risk legislation, such as enforcing protections and implementing recovery actions, will belong to the government, but decisions and actions can be advised or undertaken by expert committees and scientists under contract. It is essential that in carrying out their duties under the Act, all parties, the information that they gather, and processes that they undertake are protected from interference. Although data collection and reporting have been strongly criticized for not meeting standards of independence for some environmental legislation in B.C. and nationally (Beanlands and Duinker 1983; Haddock 2014; Casselman 2015; Cleland and Gattinger 2017; Expert Panel on the Modernization of the National Energy Board 2017; Smith et al. 2017; Darimont et al. 2018; Westwood et al. 2019) species assessment by COSEWIC as input to SARA has remained independent, providing a possible model. Measures should be included in the legislation to facilitate independence for parties collecting evidence, listing, and overseeing and planning recovery actions (as in section 16 (6) in $S A R A$ ). These would include declaration and prohibitions against perceived and real conflicts of interest, security of tenure for Oversight Committee and Recovery Team members, and sufficient funding and other administrative resources to assess, recover, and protect species under BCSARPRA. 
Box 2. (concluded)

\section{Open information}

Standards of open data have increasingly been recognized as a best scientific practice (White et al. 2013; McNutt 2014a; Munafò et al. 2017) by the Government of Canada (Gregr et al. 2017), Canada's three federal research granting agencies (Government of Canada 2016c), the European Commission (European Commission 2012), top peer-reviewed scientific journals (McNutt 2014b; Miguel et al. 2014; Nosek et al. 2016; Nature 2018), and major research funders (Bill \& Melinda Gates Foundation 2018; The Wellcome Trust 2018). All information collected and produced in accordance with the Act should be explicitly required to be available to the public (with due consideration for sensitive data, geographic locations, and (or) Indigenous or community-held knowledge), for free, without delay, in formats that are transferable, interoperable, and archived in perpetuity. Critically, data, reports, and decision-statements associated with all activities related to the Act by all stakeholders should be made available without undue delay, ideally via a web-based open data platform. It may be advisable to include commitments to submitting data as part of related professional designations (such as Registered Professional Biologist in B.C.). A coordinated and comprehensive database was recently identified as an important step towards effectively managing and recovering species at risk across Canada (Smart Prosperity 2018a).

An open data platform should serve as the primary means of public engagement and clearly explain the BCSARPRA and the roles of government and advisory bodies in enacting and monitoring the Act. Such a platform could also serve as the portal to a coordinated database, in collaboration with the federal government, which hosts its own registry related to SARA (Government of Canada 2018a) and the BCCDC, which already holds substantial data relevant to species conservation. Efforts should be made to align data warehousing methods between jurisdictions to more easily support independent analysis, data-sharing, and evaluation of cumulative effects (details about how this coordination might be done are described in Westwood et al. 2017). If well-executed, an open data platform will enable public participation, long-term monitoring and trend analysis, independent verification, effective coordination with other jurisdictions, and measurement of Act effectiveness.

\section{Take an evidence-based approach to recovery}

National and provincial species at risk legislation across Canada, including SARA and previous drafts of B.C. legislation, have typically addressed four components of species protection and recovery: (1) assessing risk status, (2) designating a legal status ("listing"), (3) applying immediate protections to individuals and habitats, and (4) planning and implementing further recovery actions. The manner in which these components are addressed varies across jurisdictions, particularly regarding the discretion exercised by government officials at each stage.

Although our proposed process for managing and recovering species at risk includes these four components, we also emphasize a fifth: (5) reporting on outcomes, with explicit criteria and indicators, to ensure government accountability towards achieving the purpose of the Act. Across all components, we recommend methods to promote expeditious, efficient, and effective implementation. This includes using an adaptive management framework in a rigorous way (Olszynski 2017): an iterative approach that examines which recovery activities are working and adjusting accordingly, with an emphasis on improving measurable outcomes. 


\section{I Mandate an Oversight Committee to prioritize assessment, list species, guide prioritization of recovery actions, and evaluate effectiveness}

In preliminary materials, the government has expressed interest in creating a committee to assess the status of species in the province (BCMECCS 2018). We suggest that this function and others be conducted by an independent Oversight Committee, whose responsibilities would include:

- $\quad$ Overseeing status assessment (section 2.2)

- $\quad$ Listing assessed species (section 2.2)

- Grouping species for recovery action planning, and defining and coordinating the planning process (section 2.3)

- $\quad$ Nominating the members of recovery teams (section 2.3)

- $\quad$ Reporting on recovery actions and outcomes (section 4)

Creating an Oversight Committee has key benefits for effective and efficient assessment and recovery of listed species. It would: (1) increase integration among provincial, federal, and Indigenous governments, academic, industry, and non-governmental sectors for species conservation and recovery; (2) ensure transparency and consistency in the assessment and recovery processes; (3) reduce costs through the coordination of multi-species recovery plans and actions; and (4) rapidly integrate advances in conservation science into implementation of the law.

Much like SARA sets out the responsibilities of COSEWIC (Government of Canada 2002), BCSARPRA ought to set out the functions and member qualifications of the Oversight Committee and ensure the provincial government provides the committee with the resources necessary to perform its functions. Members should include experts in ecological and conservation sciences who are mandated to participate independently of their affiliations (governmental, industrial, etc.); clear conflict of interest guidelines need to be developed and followed to ensure independence. Member qualifications should be in the public record, and we strongly suggest that selection of members accounts for other aspects of diversity and representation of under-represented groups. Initial committee nominations should be made by the government, and once the committee is established, additional or replacement members would be nominated by the committee itself. The relevant Minister would approve appointments, with a legal requirement to explain rejected nominations by the Minister in a written decision.

The Oversight Committee should also be required to include Indigenous Knowledge Holders in a manner decided by Indigenous peoples in B.C. One option would be to include Indigenous representatives as expert members in the Committee itself. Alternatively, or additionally, a committee could be struck, similar to the National Aboriginal Council on Species at Risk (Government of Canada 2018b) that would function as a "gatekeeper" for the appropriate exchange of Indigenous knowledge, providing advice and recommendations to the Oversight Committee and the Minister.

\subsection{Adopt automatic listing}

Legal designation (listing) of a species as "at risk" is a key step that triggers legal mechanisms for protection and recovery. Canadian jurisdictions vary in the extent to which the listing decision is discretionary (made by government) or automatic (made by an independent expert body). Under $S A R A$, assessment is done by an independent committee (and is evidence-based, with peer-reviewed reports), whereas listing is at the discretion of the Governor in Council (Government of Canada 2018c). Alberta's Wildlife Act, 2000 also uses discretionary listing. Because the application of protections may have economic or socio-cultural impacts, discretionary listing results in decisions not to list 
or lengthy delays in listing for some imperiled species (particularly those with commercial value or for which protections would impact resource industries; Elgie 2008). Ontario's Endangered Species Act, 2007 includes automatic listing based exclusively on a scientific assessment.

We recommend that the Act adopt an automatic listing system, ${ }^{6}$ involving two tracks as described in the next paragraph. An automatic listing process would support (1) scientific integrity, because listing is based on best available evidence; (2) efficacy, because all at-risk species benefit from protection and monitoring; (3) transparency, allowing for a clear statement to the public about which species are imperiled and are being recovered; and (4) timeliness, by avoiding delays related to Ministerial decisions. We recommend that the government use post-listing mechanisms (sections 2.4 and 4 ) to balance social and economic considerations with actions for species recovery.

The two tracks would be as follows: (1) automatically listing B.C. species that are listed federally under $S A R A$; and (2) separately assessing and listing species whose status requires special consideration in the province, in coordination with COSEWIC and the BCCDC as appropriate. Automatically adopting the SARA list avoids delays and costs of re-evaluation while encouraging synchronization of provincial and federal recovery efforts. Listed species would then be subject to some automatic protections (section 3.1) and enter the recovery action prioritization and tracking process.

Some species and populations will require B.C.-specific assessment, including designatable units or sub-populations in B.C. that are more at risk than their federal status indicates (e.g., red-listed species that are endangered in B.C. but only listed as special concern in Canada) and some nationallyimperiled species not listed under SARA (e.g., species identified as at risk by COSEWIC but not listed under SARA). One of the most successful components of SARA is the independent scientific assessment provided by COSEWIC (Waples et al. 2013). We recommend that the Oversight Committee be granted similar powers to propose species for assessment based on requests received for additional listings or changes in status from interested parties, including members of the public and the government. The Minister would then add species to the list at the direction of the Oversight Committee. Technical and administrative support should be provided by the government. We recommend using COSEWIC's guidelines for assessing risk, scaled appropriately to the province, as the basis of listing decisions.

In addition, emergency listings will be needed in cases where provincial extirpation may be imminent without protection, tailoring the emergency listing procedures of $S A R A$ to B.C. We also suggest provision be made for rapid assessment in cases where new information could affect listing. In all cases, we recommend that species be automatically added to the regulated list within three months of listing on SARA or of a decision to list by the Oversight Committee.

\subsection{Establish Recovery Teams for species or multi-species groups}

In line with British Columbia Task Force on Species At Risk (2011) we recommend that Recovery Teams be established to identify and prioritize recovery actions for species or multi-species groups. Multi-species recovery approaches may be employed when species overlap substantially in a particular ecoregion (ecosystem-based) or when a subset of species face clearly defined common threats (e.g., pollutants, invasive species, or a disease), which can deliver cost efficiencies over single species

\footnotetext{
${ }^{6}$ The majority of coauthors supported the model advocated in this paper: automatic listing (section 2.2) with SARA-like protections on Crown land (section 3.1) with mechanisms for permits and exceptions at the recovery planning stage (section 4). We also considered alternative listing and protection models, including (1) automatic listing and SARA-like protections on Crown land with no mechanism for exceptions, (2) discretionary listing with $S A R A$-like protections on Crown land, (3) discretionary listing with enhanced protections on Crown land, and (4) discretionary listing with $S A R A$-like protections and mechanisms for exceptions.
} 
planning (Martin et al. 2018). Several areas of B.C. have high numbers of species at risk (e.g., southern Vancouver Island Garry Oak ecosystems and South Okanagan ecosystems) that would be well-served by this approach. Multi-species coordination can address cases where recovery actions for one species may affect another (e.g., when both a predator and its prey species are at risk). There is precedent for broadly constituted Recovery Teams in B.C., including the Garry Oak Ecosystem Recovery Team and the Vancouver Island Marmot Recovery Team. We recommend that listed species be assigned by the Oversight Committee to a new or existing Recovery Team within three months of listing.

This approach is consistent with the multi-species approach that Environment and Climate Change Canada is increasingly using for SARA-listed species (Government of Canada 2018d). That said, the central goal of B.C. legislation would remain improving the status of all individual species at risk, such that recovery actions are targeted appropriately and with species-specific measures for monitoring recovery.

The Oversight Committee would be responsible for: (1) creating general guidance for Recovery Teams to ensure that priority actions use a common framework for decision-making based on the best available information on the conservation status of a species, including scientific, Indigenous, and local knowledge; (2) organizing their structure (delineating multi-species groupings while taking into account existing Recovery Teams and any recommendations made by the government, sharing best practices among Recovery Teams, and evaluating progress of Recovery Teams and restructuring if needed); (3) reporting on progress towards species recovery (synthesizing information from the Recovery Teams); and (4) nominating individuals to serve as team members. In cases where a federal Recovery Team exists, the Oversight Committee would determine whether an additional provincial team is needed.

We recommend that members of Recovery Teams be limited to experts with knowledge of the ecology, threats, socioeconomics, and recovery options for the species or species group and that they be drawn from government (including Indigenous government) and non-government sectors of society. Their qualifications should be part of the public record. Government would be responsible for appointing members and adequately funding and supporting Recovery Teams. We recommend that rejection of Recovery Team nominations received from the Oversight Committee be accompanied by a publicly available written decision statement.

\subsection{Prioritize recovery actions quickly and transparently, while aiming to recover all species}

Under the SARA process, a Recovery Strategy is developed based on scientific and Indigenous knowledge, followed by an Action Plan, with the latter incorporating socioeconomic costs and benefits. This two-step planning stage has the advantage of clearly separating scientific recommendations from management actions, encouraging transparency of decision-making. However, in practice, the preparation of these two documents causes serious delays before actions are taken. As of 2017, the average time for Recovery Strategy completion exceeded six years (J. Whitton, personal communication, 2018), double the legally-mandated time limit, and Action Plans are still missing for most listed species (beyond Plans within National Parks). Such delays have been found unlawful by the Federal Court of Canada (Western Canada Wilderness Committee v. Canada (Fisheries and Oceans) 2014) and can lead to increased costs, uncertainty for industry and other stakeholders, and lost opportunities to recover species (Martin et al. 2012, 2017). Furthermore, existing Recovery Strategies and Action Plans often lack the content needed to determine which actions are essential for recovery (e.g., many early Recovery Strategies failed to designate critical habitat, despite the legal obligation to do so, as confirmed by court decisions (Environmental Defence Canada v. Canada (Minister of Fisheries and Oceans) 2009; J. Whitton, personal communication, 2018). The lengthy and document-focused approach that has been used to implement SARA has not yet led to improved outcomes for the majority of species, and many species at risk continue to decline in status (Favaro et al. 2014; WWF-Canada 2017). 
Other jurisdictions, such as the U.S., have modernized recovery planning approaches to be more streamlined, flexible, and responsive to new information (U.S. Fish and Wildlife Service 2017).

To speed up species recovery, we propose that the BCSARPRA combine the two steps of Recovery Strategy and Action Plan into a single process, Recovery Action Prioritization (RAP). Overseen by the Recovery Team, the RAP will elicit expert opinion, evaluate risks, assess feasibility, and prioritize options for action. Experts consulted should include local and Indigenous knowledge holders from the region covered by the Recovery Team. In carrying out the prioritization, it remains critical to apply the principles of reconciliation and scientific integrity, particularly transparency. This means making it explicitly clear when management actions deviate from evidence-based recommendations for recovery and why such determinations were made. Sufficient funding and government capacity will be necessary to carry out prioritized actions (such as those described in section 3.3) and assess their effectiveness (section 4).

The RAP would be a publicly available "living document" that allows for adaptive management, and would serve in the role of a recovery plan as agreed to under the national Accord for the Protection of Species at Risk (Government of Canada 2018a), but it would be more dynamic and coordinated with prioritized actions than traditional recovery plans in Canada. We recommend that the Act explicitly require that the first version of the RAP be drafted within one year of the species being assigned to the Recovery Team and updated on a mandatory timeline (as specified by the Recovery Team) until all species under the purview of the Recovery Team are deemed recovered by the Oversight Committee (but see section 4). Upon implementing the law, there should be a "grace period" (we suggest two years) before mandatory reporting timelines come into effect, allowing for the Oversight Committee to be established and its guidance developed. The government may extend timelines with an explicit statement from the Minister, providing the rationale for the extension is published and the public are given an adequate comment period.

Evidence-based assessment is central to determining the feasibility of recovery, the targets for and measures of recovery, and the mechanisms for achieving these targets. The choice of which actions and mechanisms to implement requires input from socioeconomic analysis (Naidoo et al. 2006; Greenwald et al. 2013), Indigenous peoples, and affected communities. The RAP stage is the appropriate place in the legislation for these considerations to be recognized through the prioritization of recovery actions. In other jurisdictions, the lack of a rigorous, transparent, and repeatable approach to prioritizing recovery action has led to delays in implementation of recovery plans and, in some cases, species extinction (Martin et al. 2012; Evans et al. 2015).

We propose that BCSARPRA require Recovery Teams to evaluate and prioritize proposed recovery actions based on estimated effectiveness, benefits, and costs. Prioritization is a tool increasingly used in conservation and natural resource management to inform investment decisions by evaluating the feasibility and effectiveness of the actions, the costs of achieving the recovery of a species (e.g., financial cost of recovery, as well as lost sociocultural opportunities and (or) ecological services associated with inaction), and the associated benefits (monetary and non-monetary) of recovery (Levin and McEwan 2001; Joseph et al. 2009; Pannell et al. 2012).

The Recovery Team would be charged explicitly in the legislation with commissioning a priority list, using modern scientific tools, of the potential actions that would allow for recovery and their predicted effectiveness. There are several processes available for such a prioritization (Weitzman 1998; Carwardine et al. 2012; Chadés et al. 2015; Firn et al. 2015; Martin et al. 2018).

Minimum content for RAPs should be identified in the BCSARPRA and include (1) clear, measurable objectives and thresholds for individual species; (2) identifying critical habitat and analyzing cumulative effects; (3) describing activities likely to result in harm; (4) setting and prioritizing recovery 
actions by anticipated effectiveness, benefits, and costs; and (5) identifying methods to monitor recovery. As the RAP is intended to be a living document, in the absence of complete information (for example, if critical habitat has not yet been defined) the RAP should be published with what information is available. In cases where additional research may affect the success of recovery actions, specific further study may be included in the prioritized list of actions.

The government should be explicitly required under the legislation to provide a summary report annually to the Recovery Team on recovery activities undertaken (or not taken) as listed on the RAP and on any assessed changes to the species at risk, following explicit criteria and indicators for measuring progress. In cases where actions necessary for recovery of species are not taken, the government should explicitly account for the inaction with explanatory reasons provided in the annual summary report. The legislation should stipulate that these reasons must include a statement of what additional action will be taken to ensure the recovery objectives of the RAP will still be met or, alternatively, set out why additional actions have little to no chance of leading to recovery as set out by the RAP. We strongly caution against the government delaying actions until there remain no effective recovery measuresearly actions are more likely to prevent extinction (Martin et al. 2012, 2017). We recognize that although some species may require less effort than others to recover, the purpose of the Act is to recover all listed species. Thus, although RAPs may be made and actions prioritized for groups of species, we recommend that conservation status of listed species be tracked individually (section 4).

\section{Implement effective prohibitions and stewardship}

SARA has been hampered in its ability to recover listed terrestrial species because of the small proportion of federal land in Canada, limiting where protections automatically apply. With $94 \%$ of B.C. classified as provincial Crown land (Ministry of Forests Lands and Natural Resources Operations 2011), although much of this may be subject to Indigenous Peoples' land claims, a BCSARPRA has the advantage of being able to apply across much of the province's land base. Implementing protections will be more effective if the provincial government engages in joint recovery planning with Indigenous peoples (including through guardian programs; Indigenous Leadership Initiative 2018) and private landowners to encourage shared stewardship.

Given the wide variety of contexts and stakeholders involved in protecting species at risk, we recommend that BCSARPRA be designed with a mixture of prohibitions and incentives as detailed below. Measures that offer technical assistance, highlight co-benefits to species and to landowners where they exist, and (or) provide some regulatory relief for stakeholders undertaking stewardship actions (e.g., safe harbour habitat policies ${ }^{7}$ ) can help to obtain buy-in from multiple stakeholders (Wilcove and Lee 2004; Smart Prosperity 2018a, 2018b). Coupling information about prohibitions with stewardship options that ensure compliance while retaining landowner control and independence can further foster stewardship (using the "stick" to boost the "carrot", and vice versa). Collectively, the stewardship literature suggests that a range of incentive and assistance programs can draw in a range of landowners, allowing input from communities and other experts about what will be locally preferred and effective.

\section{I Implement automatic protections on Crown land and work with landholders to obtain additional protections}

Given that the purpose of species at risk legislation is to protect and recover species, we suggest that the Act immediately prohibit the killing, harming, taking, or harassment of individuals of endangered

\footnotetext{
${ }^{7}$ Used in the Ontario Endangered Species Act: ontario.ca/page/safe-harbour-habitat-under-endangeredspecies-act.
} 
and threatened species ("no take") on Crown land, except where the RAP specifies conditions under which take is compatible with recovery (see section 3.2). These protections should also extend to life-sustaining elements defined in the assessment, which may include ecological and (or) habitat features (e.g., dens, nests, hibernacula, other sites regularly occupied by the species, and essential geological features). Immediate legal protections were agreed to by the province as a signatory to the national Accord for the Protection of Species at Risk (Government of Canada 2018a) and should be consistent with sections 32 and 33 of SARA, which will give users on the land base greater clarity about when and how activities can be carried out without concern about imminent orders from the federal government. Where such automatic protections infringe upon Section 35 rights in the Canadian Constitution, we anticipate that the RAP will consider exceptions for Indigenous peoples, and we urge the Province to engage with Indigenous communities and governments to support conservation efforts by all parties and to identify means of compensating for any infringements.

However, "no take" protections alone are insufficient to prevent further population declines for two reasons. First, for most species indirect, cumulative, or ancillary harm from human activities are the major threats (McCune et al. 2013; Murray et al. 2018). Therefore, we recommend that RAPs specify additional protections or prohibitions essential to recovering species (including protecting critical habitat), which, if identified as a prioritized action deemed essential for recovery, must be legally required. Where such protections or prohibitions infringe upon Section 35 rights, we anticipate that the RAP will consider exceptions for Indigenous peoples. We urge that incentives rather than penalties, along with active engagement and support of Indigenous-led conservation efforts, be used when constitutional rights are affected. Recovery Teams will be tasked with evaluating stakeholder input and respecting the principles of UNDRIP when recommending priority actions. We note that in some cases, carefully managed harvest is compatible with recovery of species at risk (Polasky et al. 1997), which can be reflected in the RAP.

Second, a sole focus on prohibitions places a large burden of responsibility on those landholders whose lands are home to one or more species at risk. This burden may trigger resentment, distributional justice issues, and perverse behaviours (e.g., "shoot, shovel, and shut up" to remove the species before it triggers regulatory restrictions). Accordingly, prohibitions should be used in direct conjunction with incentive and stewardship programs, so that landowners and tenure-holders do not perceive conservation as a bad-luck lottery (Donlan 2015).

We also note that protections will not achieve their intended aims of recovering species if they are not enforced and included within a broader framework of evaluating and reducing cumulative effects. We encourage the government to motivate compliance with adequate penalties, including penalties that scale appropriately with the offence (see section 105 of $S A R A$ ) and to ensure adequate capacity is in place for monitoring and enforcement.

\subsection{Use permits and exemptions sparingly and with justification}

Permits and exemptions to powers under the Act are typical of species at risk legislation with automatic listing and are intended to dismiss or limit mandatory protections that according to government have unacceptable socioeconomic costs. Before permits or exemptions are authorized there should be a full exploration of alternatives to the proposed activity and measures to minimize the impacts of the proposed activity for the listed species (see SARA section 73(3)). Where permits or exemptions are issued, the government ought to publish the rationale for the decision and provide opportunities for public comment. In all cases, impacts to species at risk or their habitat should be offset with a mitigation plan that supports recovery efforts and results in a significant net benefit for the species or habitat in question. 
To accomplish its stated purpose, it is our view that the Act must, at minimum, legally require that no projects or activities be authorized that can jeopardize recovery of listed species or key features deemed essential for recovery (a "no jeopardy" clause; see section 73 (3)(c) of SARA and section 7 of the U.S. Endangered Species Act). RAPs can set out what activities may be consistent with recovery objectives and restrict the granting of exemptions to what is allowed under the RAP. Permits may be given for activities for which exemption is granted, or where the activity in question is beneficial to the species, or otherwise consistent with the RAP.

\subsection{Support evidence-based stewardship}

It is important for the Act not to focus solely on prohibitions in meeting its objectives. Positive stewardship actions can be very important for protecting and recovering species while generating goodwill among landowners and other parties (Mir and Dick 2012), particularly on private and Indigenous lands (Kothari et al. 2013). Landowners who oppose infringement of private land rights from endangered species legislation also described personal experiences of wonder in nature, which motivate them to value nature and its conservation (Olive and McCune 2017). Conservation tools such as tax benefits for land donations, conservation easements, reverse auctions, payment for environmental services, and "safe harbour agreements" can facilitate appropriate stewardship (Smart Prosperity 2018b). Robust stewardship programs that include local communities could not only support recovery, but also prevent the decline of other non-listed species. Effective stewardship is particularly important in B.C., where the highest densities of species at risk occur on lands that are largely privately owned.

Stewardship incentive programs should also be guided by scientific evaluations and an evidence-based approach (Robbins 2014; Schuster et al. 2018). As with prioritizing recovery actions, the effects of the stewardship initiatives on stakeholder behaviour should be evaluated and monitored, to ensure that the investments lead to added benefits for species recovery. For example, stewardship programs should avoid "industry capture", by which industry groups successfully lobby for subsidies for behaviours that should be undertaken regardless.

It is crucial to design stewardship programs that yield long-term gains for biodiversity (Chan et al. 2016) and that do not inadvertently achieve perverse results or erode existing moral motivations for conservation (Rode et al. 2015; Chan et al. 2017). For example, some payment programs effectively give landowners or tenure-holders the right to degrade habitat unless paid otherwise (Polasky et al. 1997). Programs like conservation auctions and grants that adopt a cost-sharing (rather than profityielding) approach and that appeal to stakeholder expertise and creativity are more likely to support existing motivations for conservation (Stoneham et al. 2003; Ramsdell et al. 2016; Chan et al. 2017). To be successful, incentive programs should be supported by policies that facilitate collaboration among stakeholders (Sorice et al. 2011).

\section{Ensure accountability to meeting Act objectives}

In our opinion, BCSARPRA is more likely to succeed if the Government of B.C. is held accountable for achievements and failures to protect the province's species at risk. Accountability can be achieved through transparent decision-making, including decisions to apply the powers of the Act to particular species on timelines commensurate with the threats and rates of decline, and through regular reporting to the public about species assessed to be at risk and efforts taken towards recovery.

We, thus, recommend a formal means for evaluating the effectiveness of the Act. Based on the annual summaries provided by government (section 2.4), we recommend that the Oversight Committee report annually the progress that has been made towards carrying out the prioritized actions and the impact of these actions using explicit quantitative criteria and indicators. Criteria and indicators may 
include but are not limited to: arresting decline; genuine changes in status of listed species; percentage of recommended recovery actions implemented (weighted by priority); and whether legislated timelines on assessment, listing, creation of Recovery Teams, and creation and updating of RAPs were met. Clearly, the central gauge of the law and its implementation is improvement in status of listed species (British Columbia Task Force on Species At Risk 2011). These annual reports should be publicly available for comment and scrutiny. We also recommend explicitly requiring an evaluation of the efficacy of the Act every five years (carried out by an impartial body, such as the Auditor General of B.C.) to which the Minister would be required to respond within six months. These reports should be publicly available and would emphasize demonstrable progress against a prioritized plan of action and quantitative and measurable targets for recovery.

In rare cases, it will not be possible to recover some listed species, and the legislation should provide the government with the power to cease supporting recovery actions specified by a RAP for that species. The legislation should explicitly limit the availability of this power to where the Minister forms the opinion that: (1) recovery actions have shown no positive effects on slowing or reversing population declines, and no further recovery actions set out in the RAP are reasonably expected to slow or reverse declines, or (2) the socioeconomic costs of recovery outweigh the benefits of recovery to the species and future generations. Prior to exercising this "opt-out" power, the Minister should solicit a statement from the Recovery Team about the Minister's opinion. The Minister should then be required to publish a public written statement setting out: (1) which recovery actions have been implemented to date and why they have failed; (2) the statement from the Recovery Team on the proposed exercise of this "opt-out" power; and (3) a summary of the evidentiary basis for the irrecoverability of the species or the socioeconomic case for the challenges to recovery, as applicable. The Minister should then consider and respond to the public comments before exercising this "opt-out" power. As a further means to ensure the exercise of this power does not undermine the overall objectives of the legislation, the legislation should explicitly make the exercise of this "opt-out" power subject to judicial review. Species for which the opt-out clause is invoked should still be included in monitoring and reporting of the Act.

The Act should formally recognize the public as a partner in the recovery and protection of species at risk in B.C. by providing legislated processes to enable public participation. These legislated processes should include mechanisms by which the public can request that a species be considered for assessment, the ability to comment on RAPs, the ability to comment on reporting on the Act by the Oversight Committee, the ability to comment on all Ministerial statements, and the legal opportunity to seek judicial remedies for contraventions of the Act, including failure to adhere to legislated timelines or to prioritized actions deemed essential for recovery.

\section{Conclusions}

British Columbia's varied topography and climate-from oceans to mountains to deserts-has nurtured the highest species richness in Canada. However, B.C. also includes the largest number of species under threat in Canada. An effective B.C. Species At Risk Recovery and Protection Act would protect and recover imperiled species at a time of unprecedented and ongoing environment-related challenges.

B.C. can learn from the successes, failures, and challenges of species at risk legislation in other jurisdictions to draft an Act that can better accomplish the purpose of recovering species at risk. We have made recommendations for an Act that are focused on prioritizing actions that will lead to recovery of species at risk (Box 1). Critical to these efforts are the oversight of an independent committee, independent and specialized recovery teams who use a modern approach to prioritize recovery actions for species under their purview, and a strong program for monitoring and reporting of recovery for 
all listed species, with strict adherence to reasonable timelines. In addition, we identify effective funding, enforcement, and coordination with other laws as key components for success. The features of the Act that we recommend would comply with the national Accord for the Protection of Species at Risk (Government of Canada 2018a), with the Recovery Action Prioritization serving the role of a recovery plan but providing a more rapid path towards action, focusing attention on actions likely to work, and allowing for more adaptive management in the face of evidence regarding the efficacy of actions.

By focusing on principles of timeliness, accountability, scientific integrity, stakeholder inclusion, and a commitment to evidence-supported action for recovery, we seek an Act that will promote the recovery of species at risk and simultaneously help to safeguard all of B.C.'s biodiversity. We provide these recommendations to help the province draft effective legislation that is scientifically supported and evidence-based to protect B.C.'s wild species in perpetuity. We recognize that many challenges remain between our recommendations and an effective species at risk Act, including determining a funding

Proposed model for listing and recovering species at risk

Oversight Committee

- Oversee status assessment

- List assessed species

- Group species for recovery action planning

- Define and coordinate the planning process

- Nominate members for recovery team

- Report on recovery actions and outcomes

and recommends species

for listing in consultation with

COSEWIC and BCCDC

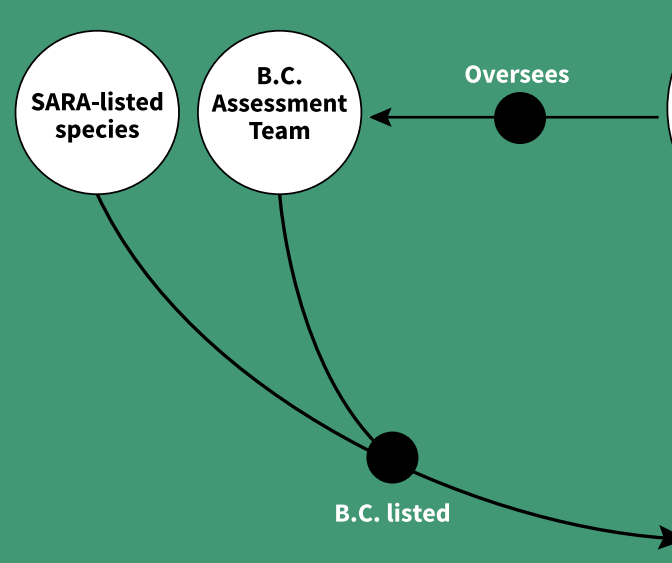

Group

Action

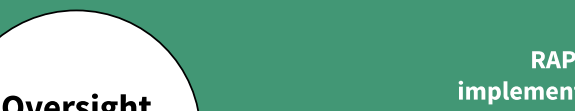

mentation

\section{Oversight}

Summary report

from government
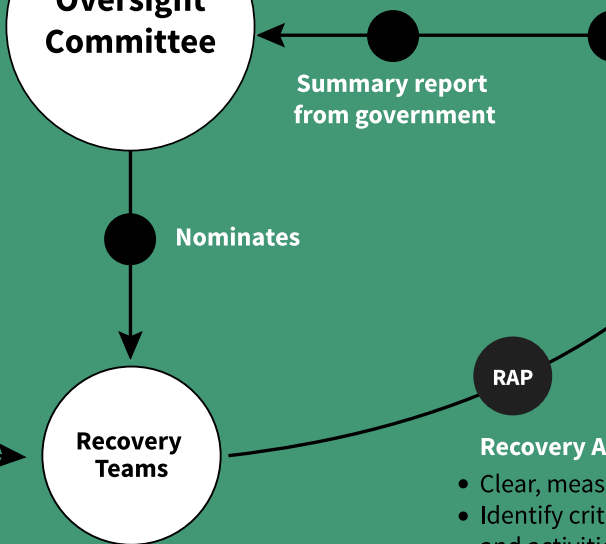

Evaluate and prioritize proposed recovery actions for all species based on estimated effectiveness and cost Committee

Nominates
Recovery Action Prioritization (RAP)

- Clear, measurable objectives

- Identify critical habitats

and activities likely to result in harm

- Prioritize recovery actions

- Methods to monitor recovery

Fig. 1. Proposed structure for an independent advisory framework aimed at identifying species at risk, prioritizing actions likely to improve the status of endangered species, and monitoring effectiveness of the actions. (Figure design: Uytae Lee.) 
mechanism that is sufficient and fair, building the political support to ensure passage, and strengthening partnerships across the province to ensure that the law is implemented and effective. We offer our recommendations to urge lawmakers to meet these challenges with a law that focuses on taking action to protect B.C.'s wild species in perpetuity.

\section{Acknowledgements}

The authors acknowledge the support of the Yellowstone to Yukon Conservation Initiative in providing a convening role and resources to develop this report. We also thank staff at the B.C. Ministry of Environment and Climate Change Strategy for guidance and helpful feedback during the planning stages of this report. We are grateful to the paper's supporters (listed at scientists-4-species.org), as well as Candace Batycki, Justina Ray, and two anonymous expert reviewers whose comments on earlier drafts substantially improved this paper. We acknowledge Uytae Lee in the design of Fig. 1 and the accompanying graphical abstract.

\section{Author contributions}

ARW, SPO, AM, CD, KEH, CJ, and BMS conceived and designed the study. ARW, SPO, AM, CD, $\mathrm{KEH}, \mathrm{CJ}$, and BMS analyzed and interpreted the data. ARW, SPO, AM, CD, KEH, CJ, BMS, CB, KMAC, MF-B, SF, SG, ALJ, DK, TGM, WJP, JDR, and JW drafted or revised the manuscript.

\section{Competing interests}

The authors have declared that no competing interests exist.

\section{References}

Akçakaya HR, Bennett EL, Brooks TM, Grace MK, Heath A, Hedges S, et al. 2018. Quantifying species recovery and conservation success to develop an IUCN Green List of Species. Conservation Biology, 32: 1128-1138. PMID: 29578251 DOI: 10.1111/cobi.13112

Artelle KA, Reynolds JD, Treves A, Walsh JC, Paquet PC, and Darimont CT. 2018. Hallmarks of science missing from North American wildlife management. Science Advances, 4: eaao0167. PMID: 29532032 DOI: 10.1126/sciadv.aao0167

Austin M, Buffett D, Nicolson D, Scudder G, and Steven V (Editors). 2008. Taking nature's pulse: the status of biodiversity in British Columbia. Biodiversity BC, Victoria, British Columbia.

B.C. Conservation Data Centre. 2018. Red or blue-listed [online]: Available from a100.gov.bc.ca/pub/ eswp/.

B.C. Ministry of Environment and Climate Change Strategy (BCMECCS). 2018. Protecting species at risk: a primer to support a conversation with British Columbians. BCMECCS, Victoria, British Columbia [online]: Available from engage.gov.bc.ca/app/uploads/sites/376/2018/05/ProtectingSpecies-at-Risk_A-Primer-Apr16_rev.pdf.

Beanlands GE, and Duinker PN. 1983. An ecological framework for environmental impact assessment in Canada. Institute for Resource and Environmental Studies, Dalhousie University and Federal Environmental Assessment Review Office, Halifax, Nova Scotia [online]: Available from publications.gc.ca/collections/collection_2018/acee-ceaa/En106-197-1983-eng.pdf.

Bill \& Melinda Gates Foundation. 2018. Gates Open Research [online]: Available from gatesopenresearch.org/. 
Bird SC, and Hodges KE. 2017. Critical habitat designation for Canadian listed species: slow, biased, and incomplete. Environmental Science \& Policy, 71: 1-8. DOI: 10.1016/j.envsci.2017.01.007

British Columbia Task Force on Species At Risk. 2011. Report of the British Columbia Task Force on Species at Risk [online]: Available from www2.gov.bc.ca/assets/gov/environment/plantsanimals-and-ecosystems/species-ecosystems-at-risk/species-at-risk-documents/speciesatrisk_ report.pdf.

Cannings S, Anions M, Rainer R, and Stein B. 2005. Our home and native land: Canadian species of global conservation concern. NatureServe Canada, Ottawa, Ontario.

Carwardine J, O'Connor T, Legge S, Mackey B, Possingham HP, and Martin TG. 2012. Prioritizing threat management for biodiversity conservation. Conservation Letters, 5: 196-204. DOI: 10.1111/ j.1755-263X.2012.00228.x

Casselman A. 2015, July. Who is watching B.C.'s environmental watch dogs? BC Business.

Chadés I, Nicol S, van Leeuwen S, Walters B, Firn J, Reeson A, et al. 2015. Benefits of integrating complementarity into priority threat management. Conservation Biology, 29: 525-536. PMID: 25362843 DOI: $10.1111 /$ cobi.12413

Chan KMA, Balvanera P, Benessaiah K, Chapman M, Díaz S, Gómez-Baggethun E, et al. 2016. Opinion: why protect nature? Rethinking values and the environment. Proceedings of the National Academy of Sciences of the USA, 113: 1462-1465. PMID: 26862158 DOI: 10.1073/pnas. 1525002113

Chan KMA, Anderson E, Chapman M, Jespersen K, and Olmsted P. 2017. Payments for ecosystem services: rife with problems and potential-for transformation towards sustainability. Ecological Economics, 140: 110-122. DOI: 10.1016/j.ecolecon.2017.04.029

Cleland M, and Gattinger M. 2017. System under stress: energy decision-making in Canada and the need for informed reform. Positive Energy, University of Ottawa, Ottawa, Ontario.

Darimont CT, Paquet PC, Treves A, Artelle KA, and Chapron G. 2018. Political populations of large carnivores. Conservation Biology, 32: 747-749. PMID: 29363171 DOI: 10.1111/cobi.13065

Donlan C. 2015. Proactive strategies for protecting species: pre-listing conservation and the Endangered Species Act. 1st edition. University of California Press, Berkeley, California. $280 \mathrm{p}$.

Elgie S. 2008. Statutory structure and species survival: how constraints on Cabinet discretion affect endangered species listing outcomes. Journal of Environmental Law and Practice, 19: 1-32.

Environment and Climate Change Canada. 2018a. Canadian environmental sustainability indicators: species at risk population trends [online]: Available from canada.ca/en/environment-climate-change/ services/environmental-indicators/species-risk-population-trends.html.

Environment and Climate Change Canada. 2018b. Progress report on unprotected critical habitat for the Woodland Caribou (Rangifer tarandus caribou), Boreal population, in Canada. Species at Risk Act Critical Habitat Report Series. Environment and Climate Change Canada, Ottawa, Ontario.

Environmental Defence Canada v. Canada (Minister of Fisheries and Oceans). 2009. Federal court decision [online]: Available from decisions.fct-cf.gc.ca/fc-cf/decisions/en/item/57043/index.do. 
European Commission. 2012. Access to and preservation of scientific information in Europe. Report on the implementation of Commission Recommendation C(2012) 4890 final-study. DirectorateGeneral for Research and Innovation, European Commission, Brussels, Belgium. 96 p. Available from ec.europa.eu/research/openscience/pdf/openaccess/npr_report.pdf.

Evans DM, Che-Castaldo JP, Crouse C, Davis FW, Epanchin-Niell R, Flather CH, et al. 2015. Species recovery in the United States: increasing the effectiveness of the Endangered Species Act. Issues in Ecology. Report No. 20. Ecological Society of America, Washington, D.C. 27 p.

Expert Panel on the Modernization of the National Energy Board. 2017. Forward, together: enabling Canada's clean, safe, and secure energy future-volume I-report of the Expert Panel on the Modernization of the National Energy Board [online]: Available from publications.gc.ca/collections/ collection_2017/rncan-nrcan/M4-149-2017-1-eng.pdf.

Favaro B, Claar DC, Fox CH, Freshwater C, Holden JJ, and Roberts A. 2014. Trends in extinction risk for imperiled species in Canada. PLoS ONE, 9: e113118. PMID: 25401772 DOI: 10.1371/ journal.pone.0113118

Firn J, Maggini R, Chadès I, Nicol S, Walters B, Martin TG, et al. 2015. Priority threat management of invasive animals to protect biodiversity under climate change. Global Change Biology, 21: 3917-3930. PMID: 26179346 DOI: 10.1111/gcb.13034

Gosselin P, Hrudy SE, Naeth MA, Plourde A, Therrien R, Van Der Kraak G, et al. 2010. The Royal Society of Canada Expert Panel: environmental and health impacts of Canada's oil sands industry. The Royal Society of Canada, Ottawa, Ontario. 440 p.

Government of Canada. 2002. Species At Risk Act. S.C. 2002, c.29. Canada [online]: Available from laws-lois.justice.gc.ca/PDF/S-15.3.pdf.

Government of Canada. 2016a. Species at risk policy principles [online]: Available from canada.ca/en/ environment-climate-change/services/species-risk-act-accord-funding/policies-guidelines/policyprinciples-2016.html.

Government of Canada. 2016b. Policy on survival and recovery (proposed). Government of Canada, Ottawa, Ontario.

Government of Canada. 2016c. Tri-agency open access policy on publications [online]: Available from science.gc.ca/eic/site/063.nsf/eng/h_F6765465.html?OpenDocument.

Government of Canada. 2018a. Species at risk public registry [online]: Available from canada.ca/en/ environment-climate-change/services/species-risk-public-registry.html.

Government of Canada. 2018b. National Aboriginal Council on Species At Risk [online]: Available from https://www.canada.ca/en/environment-climate-change/services/species-risk-act-accordfunding/act-description/national-aboriginal-council.html.

Government of Canada. 2018c. Timeline for amendments to Schedule 1 of the Species at Risk Act [online]: Available from canada.ca/en/environment-climate-change/services/species-risk-publicregistry/orders/timeline-amendments-schedule-1.html.

Government of Canada. 2018d. Pan-Canadian approach to transforming species at risk conservation in Canada [online]: Available from https://www.canada.ca/content/dam/eccc/documents/pdf/speciesrisk/pan-canadian-approach-transforming-species-risk-conservation-canada.pdf. 
Greenwald N, Ando AW, Butchart SHM, and Tschirhart J. 2013. Conservation: the Endangered Species Act at 40. Nature, 504: 369-370. PMID: 24358508 DOI: 10.1038/504369a

Gregory R, and Long G. 2009. Using structured decision making to help implement a precautionary approach to endangered species management. Risk Analysis, 29: 518-532. PMID: 19144073 DOI: $10.1111 /$ j.1539-6924.2008.01182.x

Gregr E, Granados M, Poisot T, and Kerr JT. 2017. Open data: two little words with huge implications for Canada's environmental assessment process. National Observer.

Groupe Maison Candiac Inc. v. Canada (Attorney General). 2018. FC 643. Federal Court decision [online]: Available from https://decisions.fct-cf.gc.ca/fc-cf/decisions/en/item/312139/index.do.

Haddock M. 2014. Professional reliance in British Columbia's environmental regulations. Environmental Law Centre, Faculty of Law, University of Victoria, Victoria, British Columbia.

Haddock M. 2018. Professional reliance review: the final report of the review of professional reliance in natural resource decision-making. Report to the Minister of Environment and Climate Change Strategy [online]: Available from engage.gov.bc.ca/app/uploads/sites/272/2018/06/Professional_ Reliance_Review_Final_Report.pdf.

Hagen AN, and Hodges KE. 2006. Resolving critical habitat designation failures: reconciling law, policy, and biology. Conservation Biology, 20: 399-407. PMID: 16903101 DOI: 10.1111/j.15231739.2006.00320.x

House of Commons of Canada. 2018. Bill C-69, An Act to enact the Impact Assessment Act and the Canadian Energy Regulator Act, to amend the Navigation Protection Act and to make consequential amendments to other Acts [online]: Available from parl.ca/DocumentViewer/en/42-1/bill/C-69/ third-reading.

Hunter ML Jr, Bean MJ, Lindenmayer DB, and Wilcove DS. 2009. Thresholds and the mismatch between environmental laws and ecosystems. Conservation Biology, 23: 1053-1055. PMID: 19627326 DOI: 10.1111/j.1523-1739.2009.01205.x

Indigenous Leadership Initiative. 2018. Indigenous Guardians program [online]: Available from ilinationhood.ca/our-work/guardians/.

Innovation Science and Economic Development Canada. 2018. Model policy on scientific integrity [online]: Available from ic.gc.ca/eic/site/052.nsf/eng/00010.html.

Jacob AL, Moore JW, Fox CH, Sunter EJ, Gauthier D, Westwood AR, et al. 2018. Cross-sectoral input for the potential role of science in Canada's environmental assessment. FACETS, 3: 512-529. DOI: 10.1139/facets-2017-0104

Joseph LN, Maloney RF, and Possingham HP. 2009. Optimal allocation of resources among threatened species: a project prioritization protocol. Conservation Biology, 23: 328-338. PMID: 19183202 DOI: $10.1111 / j .1523-1739.2008 .01124 . x$

Kothari A, Camill P, and Brown J. 2013. Conservation as if people also mattered: policy and practice of community-based conservation. Conservation \& Society, 11: 1-15. DOI: 10.4103/09724923.110937 
Kriebel D, Tickner J, Epstein P, Lemons J, Levins R, Loechler EL, et al. 2001. The precautionary principle in environmental science. Environmental Health Perspectives, 109: 871-876. PMID: 11673114 DOI: 10.1289/ehp.01109871

Lauck T, Clark CW, Mangel M, and Munro GR. 1998. Implementing the precautionary principle in fisheries management through marine reserves. Ecological Applications, 8: S72-S78. DOI: 10.2307/2641364

Levin H, and McEwan P. 2001. Cost-effectiveness analysis: methods and applications. 2nd edition. Sage Publications, Thousand Oaks, California. 328 p.

Martin TG, Nally S, Burbidge AA, Arnall S, Garnett ST, Hayward MW, et al. 2012. Acting fast helps avoid extinction. Conservation Letters, 5: 274-280. DOI: 10.1111/j.1755-263X.2012.00239.x

Martin TG, Camaclang AE, Possingham HP, Maguire LA, and Chadès I. 2017. Timing of protection of critical habitat matters. Conservation Letters, 10: 308-316. DOI: 10.1111/conl.12266

Martin TG, Kehoe L, Mantyka-Pringle C, Chades I, Wilson S, Bloom RG, et al. 2018. Prioritizing recovery funding to maximize conservation of endangered species. Conservation Letters, 11: e12604. DOI: $10.1111 /$ conl.12604

McCune JL, Harrower WL, Avery-Gomm S, Brogan JM, Csergo A-M, Davidson LNK, et al. 2013. Threats to Canadian species at risk: an analysis of finalized recovery strategies. Biological Conservation, 166: 254-265. DOI: 10.1016/j.biocon.2013.07.006

McLellan BN, Serrouya R, Wittmer HU, and Boutin S. 2010. Predator-mediated Allee effects in multiprey systems. Ecology, 91: 286-292. PMID: 20380217 DOI: 10.1890/09-0286.1

McNutt M. 2014a. Journals unite for reproducibility. Science, 346: 679. PMID: 25383411 DOI: $10.1126 /$ science.aaa1724

McNutt M. 2014b. Reproducibility. Science, 343: 229. PMID: 24436391 DOI: 10.1126/science. 1250475

Miguel E, Camerer C, Casey K, Cohen J, Esterling KM, Gerber A, et al. 2014. Promoting transparency in social science research. Science, 343: 30-31. PMID: 24385620 DOI: 10.1126/science.1245317

Ministry of Forests Lands and Natural Resources Operations. 2011. Crown land: indicators and statistics report. Ministry of Forests Lands and Natural Resources Operations, Victoria, British Columbia.

Mir DF, and Dick K. 2012. Conservation approaches to protecting critical habitats and species on private property. Natural Areas Journal, 32: 190-198. DOI: 10.3375/043.032.0208

Munafò MR, Nosek BA, Bishop DVM, Button KS, Chambers CD, Percie du Sert N, et al. 2017. A manifesto for reproducible science. Nature Human Behaviour, 1: 0021. DOI: 10.1038/s41562016-0021

Murray CC, Wong J, Singh GG, Mach M, Lerner J, Ranieri B, et al. 2018. The insignificance of thresholds in environmental impact assessment: an illustrative case study in Canada. Environmental Management, 61: 1062-1071. PMID: 29556722 DOI: 10.1007/s00267-018-1025-6

Naidoo R, Balmford A, Ferraro PJ, Polasky S, Ricketts TH, and Rouget M. 2006. Integrating economic costs into conservation planning. Trends in Ecology \& Evolution, 21: 681-687. PMID: 17050033 DOI: $10.1016 /$ j.tree.2006.10.003 
Nature. 2018. Availability of data, materials, code and protocols [online]: Available from nature.com/ authors/policies/availability.html.

Nichols JD, Johnson FA, Williams BK, and Boomer GS. 2018. Science alive and well in North American wildlife management. Science Advances, 4(3): eaao0167. DOI: 10.1126/ sciadv.aao0167

Nosek BA, Alter G, Banks GC, Borsboom D, Bowman SD, Breckler S, et al. 2016. Transparency and openness promotion (TOP) guidelines. OSF Preprints. DOI: 10.31219/osf.io/vj54c

Office of the Auditor General of British Columbia. 2013. An audit of biodiversity in B.C.: assessing the effectiveness of key tools. Office of the Auditor General of British Columbia, Victoria, British Columbia. $30 \mathrm{p}$.

Olive A, and McCune JL. 2017. Wonder, ignorance, and resistance: landowners and the stewardship of endangered species. Journal of Rural Studies, 49: 13-22. DOI: 10.1016/j.jrurstud.2016.11.014

Olszynski M. 2017. Failed experiments: an empirical assessment of adaptive management in Alberta's energy resources sector. UBC Law Review, 50: 697-796.

Pannell DJ, Roberts AM, Park G, Alexander J, Curatolo A, and Marsh SP. 2012. Integrated assessment of public investment in land-use change to protect environmental assets in Australia. Land Use Policy, 29: 377-387. DOI: 10.1016/j.landusepol.2011.08.002

Polasky S, Doremus H, and Rettig B. 1997. Endangered species conservation on private land. Contemporary Economic Policy, 15: 66-76. DOI: 10.1111/j.1465-7287.1997.tb00490.x

Proctor M, McLellan BN, Stenhouse G, Mowat G, Lamb C, and Boyce C. 2018. Resource roads and grizzly bears in Alberta, Canada. Technical Report [online]: Available from transbordergrizzlybearproject.ca/pdf/Proctor\%20et\%20al\%202018\%20Grizzlies\%20\&\%20Resource\% 20Roads\%20Report.pdf.

Ramsdell CP, Sorice MG, and Dwyer AM. 2016. Using financial incentives to motivate conservation of an at-risk species on private lands. Environmental Conservation, 43: 34-44. DOI: 10.1017/S037 6892915000302

Robbins J. 2014, May 14. Paying farmers to welcome birds. The New York Times.

Rode J, Gómez-Baggethun E, and Krause T. 2015. Motivation crowding by economic incentives in conservation policy: a review of the empirical evidence. Ecological Economics, 117: 270-282. DOI: 10.1016/j.ecolecon.2014.11.019

Ryder DS, Tomlinson M, Gawne B, and Likens GE. 2010. Defining and using 'best available science': a policy conundrum for the management of aquatic ecosystems. Marine \& Freshwater Research, 61: 821-828. DOI: 10.1071/MF10113

SAGE. 1999. Science advice for government effectiveness (SAGE). Council of Science and Technology Advisors Secretariat, S\&T Strategy Directorate, Industry Canada, Ottawa, Ontario.

Schuster R, Law EA, Rodewald AD, Martin TG, Wilson KA, Watts M, et al. 2018. Tax shifting and incentives for biodiversity conservation on private lands. Conservation Letters, 11: e12377. DOI: $10.1111 /$ conl.12377 
Science Integrity Project. 2015. Statement of principles for sound decision making in Canada [online]: Available from scienceintegrity.ca/.

Shackelford N, Standish RJ, Ripple W, and Starzomski BM. 2018. Threats to biodiversity from cumulative human impacts in one of North America's last wildlife frontiers. Conservation Biology, 32: 672-684. PMID: 29068083 DOI: 10.1111/cobi.13036

Sierra Legal and Environmental Law Centre. 2007. Joint submission to the Wildlife Act Review. Sierra Legal and Environmental Law Centre, Victoria, British Columbia [online]: Available from elc.uvic.ca/ documents/letter\%20-\%20Wildlife\%20Act\%20Review.pdf.

Smart Prosperity. 2018a. Species in the balance: partnering on tools and incentives for recovering Canadian Species At Risk. Smart Prosperity Report. Smart Prosperity Institute, Ottawa, Ontario. 29 p.

Smart Prosperity. 2018b. Economic instruments for protecting species at risk on private land. Policy Brief. Smart Prosperity Institute, Ottawa, Ontario. 10 p.

Smith T, Gibbs K, Westwood A, Taylor S, and Walsh K. 2017. Oversight at risk: the state of the government science in British Columbia. Evidence for Democracy, Ottawa, Ontario. 26 p.

Sorice MG, Haider W, Conner JR, and Ditton RB. 2011. Incentive structure of and private landowner participation in an endangered species conservation program. Conservation Biology, 25: 587-596. PMID: 21488955 DOI: 10.1111/j.1523-1739.2011.01673.x

Stoneham G, Chaudhri V, Ha A, and Strappazzon L. 2003. Auctions for conservation contracts: an empirical examination of Victoria's BushTender trial. The Australian Journal of Agricultural and Resource Economics, 47: 477-500. DOI: 10.1111/j.1467-8489.2003.t01-1-00224.x

The Wellcome Trust. 2018. Open Research Fund [online]: Available from wellcome.ac.uk/funding/ open-research-fund.

U.S. Fish and Wildlife Service. 2017. Recovery planning and implementation. U.S. Fish and Wildlife Service, Falls Church, Virginia.

Waples RS, Nammack M, Cochrane JF, and Hutchings JA. 2013. A tale of two acts: endangered species listing practices in Canada and the United States. BioScience, 63: 723-734. DOI: 10.1525/ bio.2013.63.9.8

Weitzman ML. 1998. The Noah's Ark problem. Econometrica, 66: 1279-1298. DOI: 10.2307/2999617

Western Canada Wilderness Committee v. Canada (Fisheries and Oceans). 2014. FC 148.

Westwood AR, Jacob AL, Boyd DR, Chan KM, Cooke SJ, Daigle RM, et al. 2017. Strong foundations: recap and recommendations from scientists regarding the federal environmental and regulatory reviews [online]: Available from http://www.y2y.net/strongfoundations.

Westwood AR, Olszynski M, Fox CH, Ford AT, Jacob AL, Moore JW, et al. 2019. The role of science in contemporary Canadian environmental decision making: the example of environmental assessment. UBC Law Review, 52: 243-292.

White EP, Baldridge E, Brym ZT, Locey KJ, McGlinn DJ, and Supp SR. 2013. Nine simple ways to make it easier to (re)use your data. Ideas in Ecology and Evolution, 6: 1-10. DOI: 10.4033/iee. 2013.6b.6.f 
Wilcove DS, and Lee J. 2004. Using economic and regulatory incentives to restore endangered species: lessons learned from three new programs. Conservation Biology, 18: 639-645. DOI: 10.1111/j.15231739.2004.00250.x

WWF-Canada. 2017. Living planet report: a national look at wildlife loss. WWF-Canada, Toronto, Ontario [online]: Available from assets.wwf.ca/downloads/WEB_WWF_REPORT_v3.pdf. 